\title{
Efficient and Clean Production Practice of Large-Scale Sintering Machine
}

\author{
Daijun WANG, ${ }^{1,2,3) *}$ Shengli WU, ${ }^{1,2)}$ Changxing $\mathrm{LI}^{3)}$ and Juan $\mathrm{ZHU}{ }^{1,2)}$ \\ 1) State Key Laboratory of Advanced Metallurgy, University of Science and Technology Beijing, Beijing, 100083 China. \\ 2) School of Metallurgical and Ecological Engineering, University of Science and Technology Beijing, Beijing, 100083 China. \\ 3) Sintering design division, Beijing ShouGang International Engineering Technology Co., Ltd., Beijing, 100043 China.
}

(Received on January 25, 2013; accepted on March 19, 2013)

\begin{abstract}
Shougang Jingtang Iron and Steel plant has built the new generation sinter plant with two $500 \mathrm{~m}^{2}$ sintering machines at Caofeidian Port, the thought of Metallurgical Process Engineering was led into, and the ordering, coordinated, efficient, continuous production of sinter manufacturing processes were achieved. Whose overall design adopted advanced, proven process technology and large-scale equipments, which broke through long flow layout in traditional metallurgical projects and achieved short flow with compact arrangement. Widening side plate of sintering machine and annular cooler were used to create conditions for increasing production capacity, lowering energy consumption of unit production. According to the concept of recycling economy and energy saving, the high-temperature exhaust heat of annular cooler was recycled, the iron and carbon waste and waste water were dissolved, which gained sinter production energy conversion, by applying dense phase pneumatic dust conveying technology, the secondary pollution of dust was avoided, the concentration of $\mathrm{SO}_{2}$ emission was below $47 \mathrm{mg} / \mathrm{Nm}^{3}$ in the flue gas. Through adopting deep bed sintering, since producing in May 2009, the equipments ran smoothly with sintering bed depth reached $860 \mathrm{~mm}$ in sintering production, qualification rate of sinter ores reached $99.71 \%$, drum index was $81.79 \%$, and the energy consumption of process was $47.70 \mathrm{kgce} / \mathrm{t}$, which attained first class domestically and internationally advanced level.
\end{abstract}

KEY WORDS: metallurgical process; new generation sinter; technology for widening side plate; integral application; deep bed sintering; automation.

\section{Introduction}

In 2005, Shougang Group arranged and implemented resettlement and transfer developing strategy, established Shougang Jingtang United Iron\&Steel Plant with steel production of 9.7 MTPA in phase I in Caofeidian Port of Hebei Province, and as the national key project of Eleven-Fifth. In order to make sintering material meet the requirements of $2 \times 5500 \mathrm{~m}^{3}$ extra large BF for stability, energy-saving, high efficiency and longevity, $2 \times 500 \mathrm{~m}^{2}$ sintering machines and their matching facilities were set up to constitute the platform of high efficiency, low cost, high benefits and clean environment of Shougang Jingtang Iron\&Steel Plant. ${ }^{1)}$ Shougang Jingtang $500 \mathrm{~m}^{2}$ large-scale sintering machine was built firstly in China and design work was hold by BSIET.

To pursue scale benefits, with the development trend the larger sintering equipments become necessary, so does the trend of metallurgical industry development. The production practice proves that large sintering machine with low investment per unit production, better techno-economic indicators, good product quality and high productivity can surely bring obvious economic benefits. Facing the current fierce

\footnotetext{
* Corresponding author: E-mail:

wangdaijun0913@163.com,wushengli@ustb.edu.cn DOI: http://dx.doi.org/10.2355/isijinternational.53.1665
}

competition in market, small and dispersed equipments with lower technical level will inevitably be replaced by large sintering equipments with feature of intensity and scale. ${ }^{2)}$ With the development of BF technology and the enlarged volume of $\mathrm{BF}$, large $\mathrm{BF}$ must be matched with large sintering equipments from the economic and rational point, thus sintering equipments become larger and more reasonable. Deep bed sintering, as the sintering technology developed in 1980 s, has been widely used and quickly developed in recent 30 years. The popular view is that deep bed sintering can improve sinter strength, increase finished product rate, reduce solid fuel consumption and total heat consumption, and decrease $\mathrm{FeO}$ content. Thus, attention should be attached to large sintering equipments as well as the advantages of deep bed sintering technologies. ${ }^{3,4)}$

\section{New Generation Sinter Process Technology}

\subsection{The Function Expansion of Sinter Production Pro-} cess

The sinter production is expanded by the new generation sinter process technology. Firstly, researches on the sinter production process, equipment, process control, operation and breakthroughs on key technologies, which help to supply sinter ore for the blast furnace with high quality, 
efficiency, low cost, stable quality. Secondly, studies and breakthroughs on the energy conversion of sinter process and key technology, the energy consumption is reduced, the waste heat utilization is improved, so that the energy consumption of process reaches the international leading level. Thirdly, studies and breakthroughs on the sinter production process waste absorption-treatment and reuse, then make the sinter production process green circulation come true.

\subsection{The Innovation on Sinter Production Process}

Using the theory of metallurgical process engineering, ${ }^{5)}$ studying the function, structure, efficiency optimization and dissipation minimization of the sinter production process, absorbing domestic and foreign advanced sinter experience, adopting dynamic and precise design theory innovation, designing the centralized fuel crushing and the cube concentration screening. From fuel crushing, proportioning, mixing, sintering annular cooler to finished screening, the sinter process is compact, the distance of material transport are shortened to the greatest extent. The ordering, coordinated, efficient, and continuous production of sinter manufacturing process is realized. The whole plant covers an area of $30 \%$ less than the conventional design, there is only 3 transfer stations. The entire sinter plant is in the international advanced level from functional sequence, space sequence, time order, etc. All list in Tables 1 and 2.

Table 1 shows: Shougang Jingtang begins the proportioning to the sinter ores are exported, the material transport only $6.05 \mathrm{~min}$, the time-consuming of production process is shortest. Table 2 shows: Compared with the production process with $2 \times 360 \mathrm{~m}^{2}$ and $2 \times 450 \mathrm{~m}^{2}$ sinter, the comprehensive technical and economic indicators are best.

\section{New Generation Sinter Equipment Technology}

Since large-scale sintering machines are the mainstream

Table 1. The comparison of process time.

\begin{tabular}{|c|c|c|c|c|}
\hline Transportation & $\begin{array}{l}\text { Time-consuming } \\
\text { (min) }\end{array}$ & $\begin{array}{c}\text { Cumulative } \\
\text { time } \\
\text { (min) }\end{array}$ & $\begin{array}{l}\text { Conventional } \\
\text { time- } \\
\text { consuming } \\
\text { (min) }\end{array}$ & $\begin{array}{l}\text { Conventional } \\
\text { cumulative } \\
\text { time } \\
\text { (min) }\end{array}$ \\
\hline $\begin{array}{l}\text { Proportioning } \\
\text { transport }\end{array}$ & 0.80 & & 0.83 & \\
\hline $\begin{array}{l}\text { Mixture } \\
\text { transport }\end{array}$ & 2.57 & 3.37 & 4.77 & 5.60 \\
\hline $\begin{array}{l}\text { Sinter cake } \\
\text { transport }\end{array}$ & 2.68 & 6.05 & 2.89 & 8.49 \\
\hline
\end{tabular}

Table 2. The comparison of three sinter production process.

\begin{tabular}{lccc}
\hline \multicolumn{1}{c}{ Content } & Shougang Jingtang & $2 \times 450 \mathrm{~m}^{2}$ & $2 \times 360 \mathrm{~m}^{2}$ \\
\hline $\begin{array}{l}\text { General plan area } \\
\left(\mathrm{Mm}^{2}\right)\end{array}$ & 0.17 & 0.25 & 0.16 \\
$\begin{array}{l}\text { sinter ore per ton } \\
\text { area }\left(\mathrm{Mm}^{2}\right)\end{array}$ & $1.60 \times 10^{-4}$ & $2.80 \times 10^{-4}$ & $2.20 \times 10^{-4}$ \\
$\begin{array}{l}\text { The relative costs of } \\
\text { infrastructure }\end{array}$ & 0.72 & 0.83 & 1.00 \\
$\begin{array}{l}\text { The relative operating } \\
\text { expenses }\end{array}$ & 0.67 & 0.81 & 1.00 \\
\hline
\end{tabular}

development of sinter technology at domestic and foreign, Shougang Jingtang sinter plant has been built based on the development and application of $500 \mathrm{~m}^{2}$ sintering machine and $580 \mathrm{~m}^{2}$ annular cooler. And the development of supporting technologies is the important premises with the application of large-scale sintering machine and annular cooler.

\subsection{Technologies for Increasing Width of Side Plate of Sinter Pallet}

The pallet of sinter was determined to adopt with 5 meters in width, and the width of pallet side plate was increased to 5.5 meters, which made the sintering area reach $550 \mathrm{~m}^{2}$ while draft area remained at $500 \mathrm{~m}^{2}$. The blind plate was adopted in Jingtang sintering project, the widened distance could ensure sufficient sintering of mixed material of the widened part by edge wind with no green material left. Through that, the sintering area would be increased by $10 \%$, the sintering output should be increased by $5 \%-12 \%$, the air consumption per ton sintering product could be lowered by $5 \%-10 \%$, and the consumption for electricity and coal would be reduced as well as the unit energy consumption accordingly.

In this case, with the investment for $500 \mathrm{~m}^{2}$ sinter, while the results for $550 \mathrm{~m}^{2}$ sinter was actually achieved, and maximized economic benefits was realized. The sinter pallet assembly was shown in Fig. 1. Successful application of this technology provides a more energy-saving and productincreasing construction concept. According to calculating, pallet with different width can reach different sintering area, for sinter whose air box is $5 \mathrm{~m}$ width, the maximal sintering area can reach $660 \mathrm{~m}^{2}$.

\subsection{Fitting Deep Bed Sintering by Sintering Equipment}

Deep bed sintering technology was applied, with the depth of $750 \mathrm{~mm}$, and maximize to $860 \mathrm{~mm}$. For large sintering machine, there are higher requirements for adaptability of each part structure of pallet due to relative longer stay of pallet in heating section and much higher temperature caused by deep bed sintering. R \& D the sintering equipment adaptation thick layer technology, the material thickness of sintering machine reaches $860 \mathrm{~mm}$ through trapezoidal distributing. In order to meet the requirements of $860 \mathrm{~mm}$ ultra-thick material layer sintering permeability, the loose feeding device is adopted. R \& D new head and rear flexible sealing means of sintering machine, pallet chute flexible dynamic seal, self-sealing pallet tailgate, new grate bar, new type insulating parts. They are all applied to large-

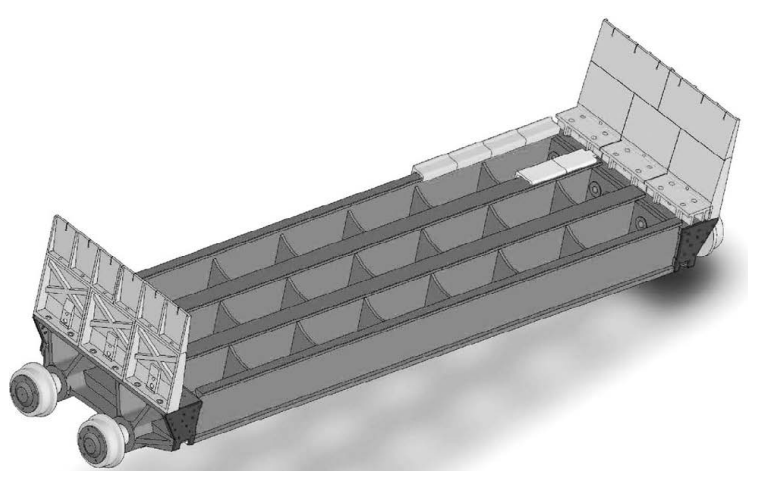

Fig. 1. Assembly drawing of sinter pallet. 
scale sintering machine, the sintering machine air leakage rate drops to $25 \%$, the power consumption downs to 36.7 $\mathrm{kWh} / \mathrm{t}$, and while reduce the maintenance cost of the pallet.

\subsection{Modification for Integrated Application Technol- ogy of Sintering Machine}

Large sintering machine with great load, have a high level of automation and installation requirements, which need a serial support of matched technique, and mainly adopt the following techniques:

(1) Adjustment technology big and small gates for mixed material.

Hydraulic system which adopt to working condition was studied and designed. That met the requirement and realized high level automatic enclosed ring control.

(2) New type flexible driving technology

In order to realize integral hoisting on the site, the imported BFT flexible drive is used, and the installation means are ameliorated independently. At the same time, the local and remote monitoring control is realized. The driving axles are increased speed measurements, and the moment protection measures are increased. The external expansion cover is first adopted on sintering machine driving device, the issues of damaging surface of principal axle caused by traditional internal expansion cover could be resolved when passing large torque. And the foundation installation connecting pedestal of new type balance device, which was designed independently and convenient to install, adjust and replace.

(3) Roll sleeve of new type pallet

Aiming at the condition of high temperature and heavy load, the domestic advanced and self lubricated roll sleeve technology with effective alloy content was adopted.

(4) Intellectual lubrication system

Domestic advanced intellectual centralized lubricating technology was adopted, which could realize on line testing and regulate flow of each point at random.

(5) Sealing technology for head and tail of air box

New type head and tail flexible sealing device was studied and developed, which could meet the large sintering production. There were special design in sectional connection, integral installation connection and dust discharge.

\subsection{Widening Technology for Pallet Of Annular Cooler}

Design specification of annular cooler in Jingtang is determined to be $580 \mathrm{~m}^{2}$ as matched requirements. Inspired by widening side plate of sintering machine pallet, design concept of using edge wind was applied to $580 \mathrm{~m}^{2}$ annular cooler, and technology for increasing side plate width of annular cooler was firstly developed with designed blowing area $520 \mathrm{~m}^{2}$ and actual cooling area reached $580 \mathrm{~m}^{2}$, the cooling area increased by $11.5 \%$, yield increased by $5 \%-$ $8.2 \%$, and air consumption of per ton sintering reduced by $5 \%-8 \%$. The annular cooler pallet assembly was shown in Fig. 2.

\subsection{Integral Application and Modification Technology of Annular Cooler}

To ensure the large annular cooler runs smoothly, a serial of technology measures are adopted, which include the following three items:

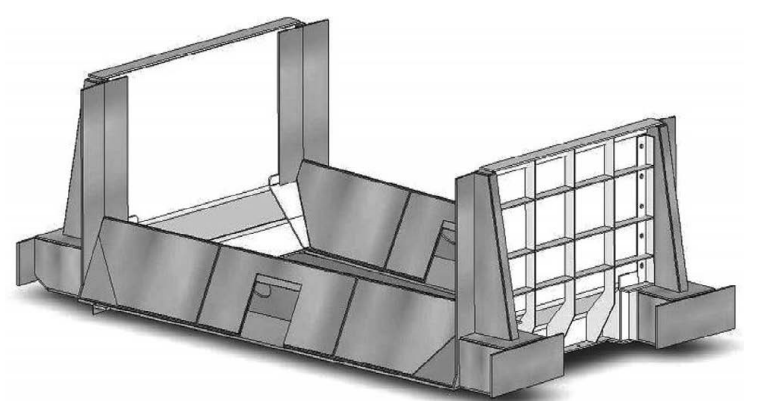

Fig. 2. Assembly drawing of annular cooler pallet.

\section{(1) Compact driving technology}

Heavy load star wheel driving device was a new type of compact driving technology dedicated to $580 \mathrm{~m}^{2}$ annular cooler. The compact driving technology had advantages of small occupying area, quick replacement, no hydraulic lubrication and less maintenance.

(2) Three-dimensional design technology for curve track

The design work of curve track was developed independently and achieved good result in actual operation. The three-dimensional design which combined space and movement as one, and accorded to strengthening curve track supporting structure integrated with features of heavy pallet.

(3) Heat and wear resistant liner plate technology for inner wall of feeding hopper

The heat resistant and wear resistant layer technologies are developed independently, and the special designed inner walls have some advantages, which include simple structure, convenient installation and replacement, easy maintenance and operating well.

\subsection{Higher Automation Technology}

Higher automation improves the controllable ability of production, ensures sintering working conditions greatly, further meets production requirements and provides support for deep bed sintering. The higher automation in Jingtang sintering system is mainly indicated by the following two aspects:

(1) Centralized monitor, and better emergency treatment, whose system meets production requirements are completed by main control office, and direct picture operational interface is adopted in main control room. There are 24 wall mounted LEDs which can control and monitor the operation of all equipments.

(2) The self-developed sintering intellectual closed loop control system, which is divided into process automatic control and quality automatic control. Process automatic control modules include many aspects, such as automatic control for storage of return ore bin, automatic control for moisture of mixed material, automatic control for sintering ignition, automatic control for distribution and speed of sintering machine, automatic control for sintering uniformity, and automatic control for sintering terminal. There two aspects include in quality automatic control modules, for example sinter ore closed loop control and sintering $\mathrm{FeO}$ closed loop automatic control. The sintering intellectual closed loop control system can realize automatic regulation based on function of each module to cancel the operational right of staff on each working position. Through sintering intellectual closed loop control system, a 
great leap for sintering control level was realized and brought the improvement of various index of sintering product, which was hard to reach by manual.

\section{Practicing Efficient Sinter Technologies}

The theoretical basis of the deep bed sintering process is "sinter layer automatic regenerative principle", which provides the possibility of the sintering process energy saving, and creates favorable conditions for the low-temperature sintering technology, as well as is good at improving the quality of sinter ore. ${ }^{6,7)}$

The deep bed sintering developed in the $1980 \mathrm{~s}$ as sintering technology, is widely used and rapidly developed in nearly 30 years. Production practice shows: The deep bed sintering can improve sinter strength, improve the yield, cut down solid fuel consumption and total heat consumption, reduce $\mathrm{FeO}$ content and enhance the reducibility. ${ }^{8)}$ The efficient sinter technologies are carried out through the following seven aspects.

\subsection{Automatic Proportioning System}

Precise proportion has great relationship with stability of sintering production. The control system of American Rockwell Company was adopted in Jingtang sintering, which was composed of class I control system and process control system. Class I control system mainly conducts datum collection, treatment, display and record, as well as datum setting and production operation during full sintering production process, and executes continuous regulation control and logic sequence control toward production process. Process control system mainly conducts operation guidance, working management, module calculation, datum treatment and storage, communication during production process, which is also called expert control system or Class II system. $\left.{ }^{9}\right)$ The structure of Class II is shown Fig. 3.

Proportioning system aims at controlling the chemical components of sintering product, and the key point is to set proportioning ratio to realize constant charging and precise control. Optimized proportioning module and proportioning dynamic control module is mainly used in proportioning system.

\subsection{Intensified Mixed Balling}

After proportioning, the material is sent by belt conveyer to mixing process for primary and secondary mixing. Drum mixer is adopted for mixing. Purpose of primary mixing is to add water and mix sufficiently, or have part function of balling. In secondary mixing, its main purpose is balling besides continuing mixing and makes the mixed material have proper moisture content. In the past, production of most domestic sintering plants was affected due to lack of balling time for the mixed material during mixing. Combined with the actual production practice, Jingtang optimized the mixing and balling time. ${ }^{8)}$

Primary mixing adopts 2 sets $\psi 4.4 \times 18 \mathrm{~m}$ drum mixer, with installation angle $3.0^{\circ}$, filling ration: $14.1 \%$, mixing time: $2.4 \mathrm{~min}$. Direct circular water was added in primary mixing and used as production process water. And 2 sets $\psi 5.1 \times 28 \mathrm{~m}$ drum mixer was adopted in secondary mixing with installation angle: $2.5^{\circ}$, filling ration: $11.2 \%$, mixing time: $4.16 \mathrm{~min}$. Hydraulic was provided to ensure balling effect and improve permeability by realizing step less speed regulating as per production requirements. Meanwhile, infrared moisture meter was used to conduct on line detecting moisture of mixed material. Frontback mode of PLC system can automatically control water added. Water was mainly added in primary mixing, and in secondary mixing, water was added for trimming regulation. The set value of water to be added was calculated by computer according to material water content and water amount to be added was given for primary mixing ( $80 \%$ of total water to be added) and secondary mixing respectively, and control flow rate of pipe valve. Final water content of mixed material was detected by infrared moisture meter of discharging belt of primary mixing and secondary mixing, and then feedback by PLC system to regulate water amount to be added in primary and secondary mixing for the proper water amount.

\subsection{Preheating Mixed Material}

To reach necessary sintering temperature, lower resistance of over-wet layer and increase mixed material temperature close to temperature of dew point, the negative effect on sintering by over-wet layer can be reduced or eliminated to improve permeability of material layer and quality of sintering product. In Jingtang sinter, low pressure steam generated by residual heat of annular cooler, which was used to produce hot water to preheat mixed material in secondary mixer for increasing material temperature and permeability. At the same time, steam preheating measures were taken in

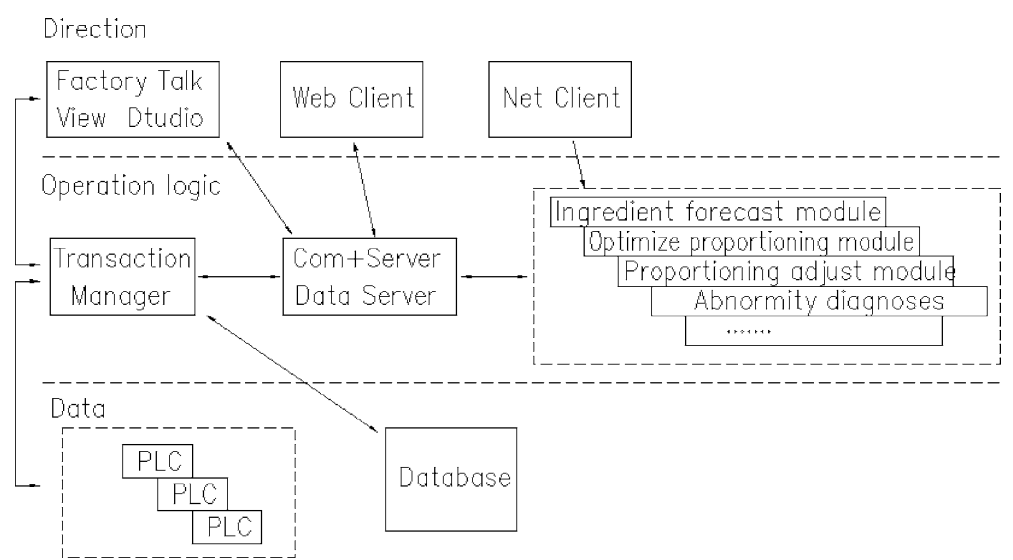

Fig. 3. Class II structure. 
surge ore bin before sintering machine, so as to increase material temperature as high as possible, and the steam was generated by residual heat of annular cooler. Temperature of mixed material can be increased over $65^{\circ} \mathrm{C}$ through these two measures and permeability of material layer was also improved, which can not only realize preheating mixed material and increasing temperature, but also use the residual heat comprehensively.

\subsection{Shuttle and Roll Type Distribution}

Shuttle distributor was provided to reduce segregation of mixed material in distributing ore bin. Round roller plus nine roll distributing means was adopted, big and six small gates were provided for round roller, opening of big and small gates could be regulated automatically through hydraulic mechanism. The evenness of distribution could be ensured by adjusting rotating speed of round roller and openness of big and small gates. Through regulating rotating speed of nine rolls, sized distribution of mixed material on the pallet can be improved to increase permeability of material layer and improve sintering temperature difference between upper and lower material layer, thus to reduce ore return rate and increase strength of sintering product.

During sintering production, rotating speed of nine rolls was developed continuously, and size distribution of mixed material on the pallet was improved. Sintering permeability was obviously improved by lowering rotating speed of nine rolls from $35 \mathrm{r} / \mathrm{min}$ to $22 \mathrm{r} / \mathrm{min}$ through several months practice.

\subsection{Stabilizing Sintering End}

In order to stabilize the end position of sinter, and make good control of the speed of vertical sinter. Four curve fitting methods are adopted to analyze the temperature of wind box exhaust gas, developing the advanced judgment criterion of sinter temperature and sinter end, which can provide a scientific basis for controlling BTP (Burning Through Point) precisely. How to realize BTP and BRP (Burning Rising Point) judging accurately? The method of temperature curve slope feature extraction is used, which can be suitable for the condition of the fluctuation, see the Fig. 4 .

Figure 4 shows the two conditions of temperature rise similarly, if applying the method of fixed parameter will obtain two results, but using the slope method can avoid this situation.

(1) Using the least square method to analyze the exhaust gas temperature for a four curve fitting, which will obtain the real reaction operating curve, and lay the foundation of accurate judging.

(2) Applying the slope method to analyze the curve, which will reach the precise station of BTP and BRP, comparing with traditional manual judgment accuracy improvement, the accuracy rate reaches $99 \%$.

(3) Adopting the method of direct control BRP and indirect control BTP, which can reduce the adjustment time $40 \%$ of BTP, the BTP stable rate reaches $98 \%$.

(4) Using the differential method to analyze sintering machine in the width direction of vertical sintering speed, which can guide charging process quantitatively, eliminate sinter process uniformity and reduce the rate of return ore.

\subsection{Controlling FeO Content}

$\mathrm{FeO}$ content in sintering product exists in the form of $\mathrm{Fe}_{3} \mathrm{O}_{4}$ combined with $\mathrm{Fe}_{2} \mathrm{O}_{3}, 2 \mathrm{FeO} \cdot \mathrm{SiO}_{2}$ combined with $\mathrm{SiO}_{2}$, and $\mathrm{CaO}_{\mathrm{x}} \cdot \mathrm{FeO}_{2-\mathrm{x}} \cdot \mathrm{SiO}_{2}$ combined with $\mathrm{CaO}$, as well as small amount of $\left.\mathrm{FeOx} .{ }^{10}\right) \mathrm{FeO}$ content can directly affect cold strength, reduction and RDI of sintering product. Thus $\mathrm{FeO}$ content shall be controlled within a reasonable range as per raw material structure and sintering operational system, if higher content, then forming of ferrite calcium binding phase will be suppressed, result in bad sintering uniformity and deteriorate sintering process. If lower content, amount of liquid phase will be seriously short and sintering drum strength will be seriously affected. ${ }^{11)}$

Main ferrous material for Shougang Jingtang is composed of Brazil hematite and Australian limonite plus local iron ore fines, and $\mathrm{FeO}$ radix was controlled within $7 \%$ in the beginning of start-up, while $\mathrm{FeO}$ radix for $495 \mathrm{~m}^{2}$ sintering machine of Bao Steel was $8 \%$. Combining with its own conditions and BF characters, and drawing on the production experiences of other enterprises, $\mathrm{FeO}$ radix of sintering product was gradually increased from $7 \%$ to $7.5 \%$ and further to $8 \%$ after some time for actual production. Drum strength and reduction disintegration property index was also increased obviously. For the index, please refer to Table 3.

Table 3. The change of sintering strength before and after adjustment of $\mathrm{FeO}$ content.

\begin{tabular}{cccc}
\hline Item & $\begin{array}{c}\text { FeO content } \\
(\%)\end{array}$ & $\begin{array}{c}\text { Drum strength } \\
(\%)\end{array}$ & $\begin{array}{c}\text { RDI index } \\
(+3.15) \%\end{array}$ \\
\hline Before adjustment & 7.00 & 78.36 & 65.70 \\
After adjustment & 8.00 & 81.79 & 70.00 \\
\hline
\end{tabular}

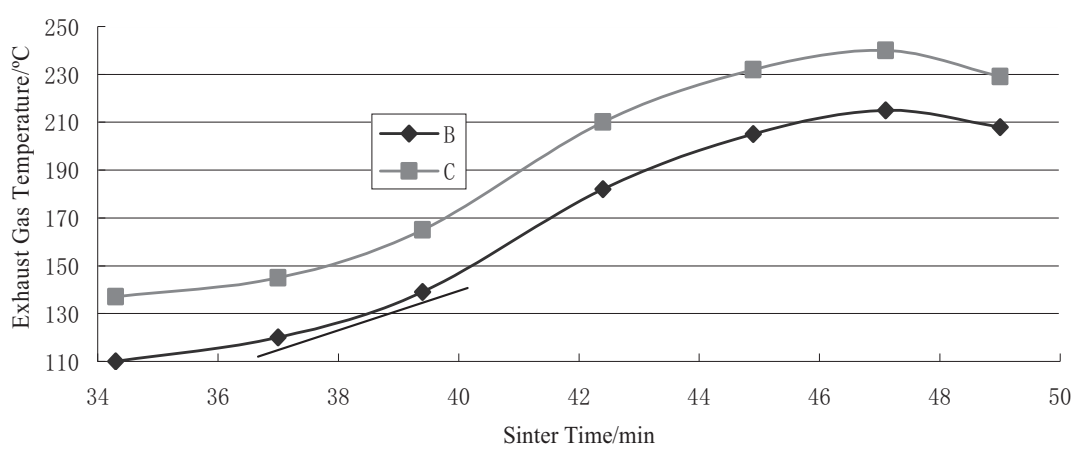

Fig. 4. The temperature curve of air boxes. 


\subsection{Reduction of Resource Production Technology}

At the end of $1980 \mathrm{~s}$ and the early $1990 \mathrm{~s}$, the high-temperature behavior of iron ore in sintering process was paid attention to. ${ }^{12-14)}$ At the beginning of 21 st century, the iron ore sintering basic characteristics of concept was put forward, and formed a set evaluation index and method based on the sintering process of iron ore powder in high temperature performance. ${ }^{15,16)}$ On that basis, the theory system and key technology of complementary characteristics that based on the technology of sintering optimization ore matching was established, ${ }^{16)}$ and get more and more extensive application in production. ${ }^{17-20)}$

The Mosaic EmBedding Iron Ore Sintering was put forward by E. Kasai. ${ }^{21)}$ Whose purpose was to use the lowquality iron ore fines resource (semi-limonite types of Mara Mamba ore). Usually the Mara Mamba ore sintering, because of its fine granularity, easy to melt, low liquid fluidity, as result the yield and quality indicators are poor. In Japanese iron and steel enterprises, the ratio of the relatively low price of low-grade ore limonite and Marra Mamba ore is up to $60-70 \%$. In the absence of a preformed particle technology and investment in new equipment condition, the ratio of limonite and Marra Mamba ore can reach 50-60\% in Shougang Jingtang. Through exploiting the ore characteristics and regulating, making full use of different ore characteristics to optimize ore blending. The ratio of $\mathrm{SiO}_{2}$ content $9-16 \%$ inferior ore reaches $5-10 \%$, the inferior ore total ratio reaches $60-70 \%$, which close to the advanced Japanese iron and steel enterprises.

In practice, Hainan ore ratio increases $2 \%$, the high content Baka ore ratio increases $5 \%$, at the same time, Brazil ore and Australia ore ratio reduce $7 \%$. On the premise of the close liquid phase sintering aggregates, the liquid phase fluidity is increased, the sinter ore quality is improved also. While implementing the matching ore method of 3-6\% boron iron ore, slag and other high $\mathrm{MgO}$ iron-containing material instead of imported iron ore $3-5 \%$ and $\mathrm{MgO}$ containing flux $1 \%$, and solving the difficult problems of complex ore and iron and steel industry typical solid waste in sintering application proportion to increase more than $3 \%$. The waste is absorbed, the resources are expanded, the resource reduction production could be realized finally.

\section{Centralized Sizing Process}

The sinter sizing process was showed in Fig. 5. Hot sintering cake discharged from sintering machine was crushed below $150 \mathrm{~mm}$ by single roller crusher and sent to annular cooler. After cooling, they were sent to product screening room for centralized sizing by slat feeder and belt conveyer. The product was divided into big product with size over 20 $\mathrm{mm}$, hearth layer with size: $12-20 \mathrm{~mm}$, and small size product with size: $5-12 \mathrm{~mm}$ and return ore: $<5 \mathrm{~mm}$. Three-time screening process and four screening series were provided in screening process, one sintering machine corresponded with 2 screening series, three cold ore screen for each series and 12 cold ore screen in total. Treating capacity for each screen was $1200 \mathrm{t} / \mathrm{h}$, when screen in one series failed, screen in the other series would be started for normal production. ${ }^{22)}$

Specification for primary screen is $3.8 \mathrm{~m} \times 10 \mathrm{~m}$ with sieve

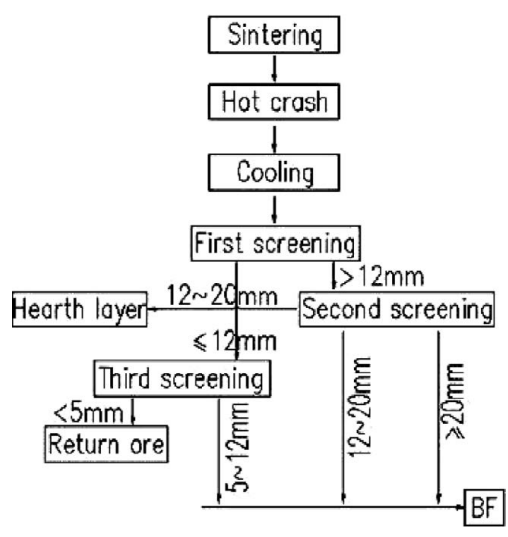

Fig. 5. The sizing process flow.

pore: $12 \mathrm{~mm}$. After primary screening, oversize $>12 \mathrm{~mm}$ will enter secondary screening for further sizing. Undersize 0-12 mm enters third screening to continue sizing. Specification for secondary screening is $3.8 \mathrm{~m} \times 7.5 \mathrm{~m}$, with sieve pore: $20 \mathrm{~mm}$. Oversize $>20 \mathrm{~mm}$, as the big product, will be sent to BF ore bin by belt conveyer. Under size $12-20 \mathrm{~mm}$ will be used as hearth layer and sent to hearth layer bin in sintering main building, the balance part of 12-20 mm will be sent to BF ore bin by small product belt conveyer as finished product through belt conveyer, material distributor. The specification for the third-time screening is $3.8 \mathrm{~m} \times 10.6$ $\mathrm{m}$, with sieve pore: $5 \mathrm{~mm}$, oversize $5-12 \mathrm{~mm}$ will be sent to $\mathrm{BF}$ ore bin by belt conveyer as small product, undersize $0-5 \mathrm{~mm}$ will be returned to sintering proportioning room for proportioning as return ore. Finished product are divided into big product $>20 \mathrm{~mm}$, balanced hearth layer and small product $5-20 \mathrm{~mm}$, and finished product will be sized and sent to BF.

\section{The Energy Conversion Technology of Sintering Production}

\subsection{Residual Heat Recycling Technology of Annular Cooler}

Based on design concept of recycling economy, energy saving and emission reduction, high temperature offgas in primary cooling section goes through hot blast pipe on fume hood and after being dedusted by heat resisted multicyclone deduster enters into high pressure over heater, high pressure evaporator and high pressure water preheater in high temperature section in sequence, and then goes into low pressure evaporator, low pressure water preheater in high temperature section through offgas pipe in sequence, and then is sent back to cooling air pipe of annular cooler as cooling air through recycling air fan. The designed capacity for over heat steam is $40 \mathrm{t} / \mathrm{h}$, over heat steam pressure 1.1 $\mathrm{MPa}$, saturated steam $\geq 12 \mathrm{t} / \mathrm{h}$, saturated steam pressure $0.3 \mathrm{MPa}$, the steam produced will provide for use in sintering plant. One part of low temperature offgas in secondary cooling section of annular cooler will be emitted to air through water preheater in low temperature section, the other part will be used to unfreeze in unfreeze house in winter guided by pipe.

This technology can not only fully recover heat from hot fume of annual cooler, but also improve the phenomenon of 
Table 4. The index of changing.

\begin{tabular}{ccccr}
\hline $\begin{array}{c}\text { Wind } \\
\text { temperature } \\
\left({ }^{\circ} \mathrm{C}\right)\end{array}$ & $\begin{array}{c}\text { Utilization } \\
\left(\mathrm{t} / \mathrm{m}^{2} \cdot \mathrm{h}\right)\end{array}$ & $\begin{array}{c}\text { Solid fuel } \\
\text { consumption } \\
(\mathrm{kgce} / \mathrm{t})\end{array}$ & $\begin{array}{c}\text { Drum } \\
\text { strength } \\
(\%)\end{array}$ & $<5 \mathrm{~mm}(\%)$ \\
\hline 25 & 1.41 & 45.85 & 80.29 & 13.32 \\
130 & 1.49 & 43.85 & 81.79 & 1.32 \\
The value changes & +0.08 & -2.00 & +1.50 & -12.00 \\
\hline
\end{tabular}

affecting sintering product quality due to directly cooling high temperature sintering product by cold air, thus make the sintering product cool down gradually and increase quality of sintering product. As indicated by production record, solid fuel will lower $2 \mathrm{kgce} / \mathrm{t}$ when cooling air temperature of annular cooler is increased from $25^{\circ} \mathrm{C}$ to $130^{\circ} \mathrm{C}$, the index of changing was shown in Table 4.

\subsection{Sintering Production Resource}

In the new generation sintering system, the iron and carbon wastes are recycled and reused as sintering materials in the steel process centered at $\mathrm{Fe}$ and $\mathrm{C}$ resources. They include most waste in steel process, such as stockyard environmental dust, coking carbon dust, sintering electrical field dust, sintering environmental dust, BF environmental dust, BF cyclone dust, BF dry dust, slag, iron sheet, CF first dust, CF secondary dust, fatlute, etc. Most of them are used as sintering materials while part of them as sintering fuel. The new generation sintering system is an important part of new generation steel process to achieve circular economy. It is also an important measure to adapt to the situations of iron ore and coal resource deterioration and insufficient, as well as reduce production cost and increase enterprise competitiveness.

\subsection{Sintering Production Clean}

The new generation sintering system is established in "low waste process". The solid wastes generated from sintering process include electrical fly ash, environmental fly ash and return ores, etc, which can be recycled and reused by sintering process. In order to remove spot ash, transportation technology has been R\&D. The fly ash generated from dust-cleaning apparatus is transported through sealed pipeline to fly ash bunker in proportion room for reusing, which had no secondary raise dust and achieved zero release. The new generation sintering system also can digest waste water generated from other steel process. Four sets of electrostatic dust collectors of $430 \mathrm{~m}^{2}$ are adopted for the big flue at sintering machine head and low pressure pulse bag filter was chosen whose collection efficiency is $99 \%$. The dust emission concentration is controlled below $20 \mathrm{mg} /$ $\mathrm{Nm}^{3}$. The half dry desulfurization process was used in sintering flue gas desulfurization, the efficiency is $98 \%$. The process has some advantages, which could dispose large quantity of gas and has strong system adaptive ability. The price of absorbent is low but the use ratio is high, the concentration of $\mathrm{SO}_{2}$ in discharged gas is below $47 \mathrm{mg} / \mathrm{Nm}^{3}$.

\section{Application Effects}

Shougang Jingtang $1 \# 500 \mathrm{~m}^{2}$ sintering machine was for-
Table 5. The main technical guideline of Jingtang $500 \mathrm{~m}^{2}$ sinter.

\begin{tabular}{lr}
\hline Bed depth $(\mathrm{mm})$ & 860.00 \\
Qualification rate $(\%)$ & 99.71 \\
Drum index $(\%)$ & 81.79 \\
Consumption of solid fuel $(\mathrm{kgce} / \mathrm{t})$ & 43.85 \\
Consumption of gas $(\mathrm{MJ} / \mathrm{t})$ & 44.46 \\
Consumption of electrity $(\mathrm{kWh} / \mathrm{t})$ & 36.70 \\
Process energy consumption $(\mathrm{kgce} / \mathrm{t})$ & 47.70 \\
Sintering area per person $\left(\mathrm{m}^{2} / \mathrm{person}\right)$ & 15.28 \\
\hline
\end{tabular}

Table 6. The comparisons of production index.

\begin{tabular}{lcccc}
\hline \multicolumn{1}{c}{ Name } & $\begin{array}{c}\text { Utilization } \\
\mathrm{t} / \mathrm{m}^{2} \cdot \mathrm{h}\end{array}$ & $\begin{array}{c}\text { Drum } \\
\text { index } \\
\%\end{array}$ & $\begin{array}{c}\text { Solid fuel } \\
\text { consumption } \\
\mathrm{kgce} / \mathrm{t}\end{array}$ & $\begin{array}{c}\text { Process energy } \\
\text { consumption } \\
\mathrm{kgce} / \mathrm{t}\end{array}$ \\
\hline $\begin{array}{l}\text { Jingtang sinter } \\
\text { plant }\end{array}$ & 1.49 & 81.79 & 43.85 & 47.70 \\
$\begin{array}{l}\text { Domestic Iron and } \\
\text { Steel plants }\end{array}$ & 1.36 & 77.98 & 55.00 & 58.20 \\
$\begin{array}{l}\text { Asian Iron and } \\
\text { Steel plants }\end{array}$ & 1.47 & 78.20 & 51.60 & 53.00 \\
\hline
\end{tabular}

mally put into production in May, 2009, with the depth of $750 \mathrm{~mm}$. After hot load test for one week, every system ran stably, and product quality met the requirements of $5500 \mathrm{~m}^{3}$ BF. In December, 2009, 2\# $500 \mathrm{~m}^{2}$ sintering machine successfully conducted hot test with bed depth of $750 \mathrm{~mm}$, and 16 hours after the test, qualified sintering product was sent to $\mathrm{BF}$ ore bin.

Currently, 1\# sintering machine has run for 3 years, and 2\# sintering machine has run for 2 years, during this period, for the purpose of keeping optimizing each production index and increasing control level, effective operation and management means was set up specifically toward features of large sintering machine by continuous exploring and summarizing production experience, which mainly showed:

(1) Bed depth was increased from $750 \mathrm{~mm}$ to $860 \mathrm{~mm}$ with higher product quality and lower energy consumption.

(2) Automatic closed loop control system for the operation of large sintering machine, including closed loop of sintering alkalinity, mixed material moisture, sintering machine speed and carbon of mixture, was developed in different stages.

(3) Coke dust bin was added, solid waste was recovered and energy consumption reduced.

(4) Quick lime assimilator and dust generating point of primary mixer was guided into wet deduster according to the characteristics of dust for further improving production environment.

(5) The production ran smoothly and each index reached advanced level since the start up in May, 2009. The main technical indicators were showed in Table 5.

Comparisons for main production index between Jingtang sinter, domestic Iron and Steel plants and Asian iron and steel plant from January to November, 2010 were showed in Table 6.

As showed in Table 6: each index has reached advanced level, which fully reflects advantages of large sintering 
Table 7. The grain size composition of finished sinter product (\%).

\begin{tabular}{lcccccc} 
Sinter ore & $>40 \mathrm{~mm}$ & $40-25 \mathrm{~mm}$ & $25-16 \mathrm{~mm}$ & $16-10 \mathrm{~mm}$ & $10-5 \mathrm{~mm}<5 \mathrm{~mm}$ \\
\hline Big product & 36.28 & 43.61 & 18.52 & 1.59 & 0 & 0 \\
Small product & 0 & 0 & 29.12 & 34.13 & 35.43 & 1.32 \\
\hline
\end{tabular}

machine like better sintering quality, lower solid fuel consumption and process energy consumption.

Since start-up of Jingtang sinter plant, nearly 3 years practice proved that the centralized sizing screening system ran smoothly, better sizing effect for both big and small product, and Table 7. showed constitution of grain size. Better material condition ensured smooth operation of Jingtang $5500 \mathrm{~m}^{3}$ BF through sizing supply. In addition, this system featured less maintenance, low maintaining cost and power consumption.

\section{Conclusions}

(1) The new generation sinter process of Shougang Jingtang, the metallurgical engineering process thought was led into. The dynamic-precision design theory was adopted, and the function of sinter production process was expanded. Studying the function, structure, efficiency optimization and production process dissipation minimize of sinter. The order, coordinated, efficient, and continuous production of sinter manufacturing process is realized. Ton of sinter ore covers an area $160 \mathrm{~m}^{2}$, especially the material transporting accumulates time is $6.04 \mathrm{~min}$.

(2) Researching and applying the technology of widening side plate of sintering machine, and the sintering equipments are suitable for technologies of deep bed sintering. Which make the sintering area reach $550 \mathrm{~m}^{2}$, while draft area remains at $500 \mathrm{~m}^{2}$, and actual and maximum bed depth reaches $860 \mathrm{~mm}$ while designed bed depth is $750 \mathrm{~mm}$, thus could realize maximized benefits for the project. The technology of increasing side plate width of annular cooler, which is developed with designed blowing area $520 \mathrm{~m}^{2}$ and actual cooling area reaches $580 \mathrm{~m}^{2}$. The cooling area is increased by $11.5 \%$, sintering product is increased by $5 \%-$ $8.2 \%$, and air consumption per ton sintering is reduced by $5 \%-8 \%$.

(3) Higher automation level increase controllable ability of production, and guarantee stable sintering working conditions greatly. Automatic proportioning intensified mixing and balling, as well as three step centralized sizing, they are all applied with high automation during implementing deep bed sintering process. Higher automation level could realize operation level beyond manual operation, furthermore achieve a fundamental leap for sintering control level and cause the increase of each sintering indicator.

(4) The recycling economy and energy conservation design concepts are applied in Shougang Jingtang new generation sinter plant, recycling high-temperature exhaust heat of the annular cooler, absorbing iron, carbon waste and waste water of the steel process. The sinter production energy conversion is realized, the dense phase pneumatic ash conveying technologies are applied, and the dust pollution is avoided again. The concentration of $\mathrm{SO}_{2}$ emission is below $47 \mathrm{mg} / \mathrm{Nm}^{3}$ in the flue gas.

(5) Since put into production, the sinter layer thickness is improved from $750 \mathrm{~mm}$ to $860 \mathrm{~mm}$ in the new generation sinter plant of Shougang Jingtang, the production runs smoothly. The indicators have reached the advanced level, which plays a role model in the metallurgical industry.

\section{REFERENCES}

1) S. Wu and D. Wang: Iron Steel, 47 (2012), 2.

2) H. Wang, G. An, Q. Wang and F. Shi: Sinter. Pelletiz., 35 (2010), 47.

3) X. Gao: Iron Steel, 43 (2008), 88.

4) T. Xia, Z. Li and Q. Yan: Sinter. Pelletiz., 30 (2005), 45.

5) R. Yin: Metallurgical Process Engineering, Metallurgical Industry Press, Beijing, (2004), 99.

6) Y. Zhang: Metall. Auto., 2 (2010), 486.

7) S. Wu and D. Chen: J. Univ. Sci. Technol. B., 32 (2010), 164

8) S. Wu and D. Chen: Iron Steel, 45 (2010), 16.

9) D. Wang and S. Wu: Asia Steel Int. Conf. 2012, Asia Steel 2012, Beijing, (2012), 13.

10) X. Feng: Sinter. Pelletiz., 29 (2004), 9.

11) G. Sun: National Sintering and Pelletizing Technical Exchanges Annual Meeting Proc., Metallurgical Industry Press, Beijing, (2009), 67.

12) S. Wu, E. Kasai and Y. Omori: Proc. of 6th Int. Iron and Steel Cong., ISIJ, Tokyo, (1990), 15.

13) L. Yan, S. Wu, Y. You, Y. Pei and L. Zhang: J. Univ. Sci. Technol. B., 32 (2010), 299

14) Y. Hida, J. Okazaki, K. Ito and S. Hirakawa: Tetsu-to-Hagané, 78 (1992), 1013.

15) S. Wu and K. Mi: The Chinese Society of Metals Iron Annual Conference, Metallurgical Industry Press, Shanghai, (2000), 161.

16) S. Wu and Y. Liu: J. Univ. Sci. Technol. B., 24 (2002), 254

17) L. Cao: Sinter. Pelletiz., 30 (2005), 5.

18) L. Zhai and M. Zhou: An-gang Techonol., 15 (2007), 12.

19) H. Li, S. Wu and Q. Li: Shandong Metall., 29 (2007), 30.

20) Q. Deng, S. Wu and H. Han: Sinter. Pelletiz., 34 (2009), 11.

21) E. Kasai, S. Komarov and K. Nushiro: ISIJ Int., 45 (2005), 538.

22) H. Wang: Sinter. Pelletiz., 36 (2011), 12. 